\title{
Pendidikan Akhlak Peserta Didik dan Pendidik Dalam Perspektif Hadis Nabi
}

\author{
Nur Laily Fauziyah \\ STIT Al Marhalah Al Ulya Bekasi \\ Email: lailyfauziyah@gmail.com
}

\begin{abstract}
Morality is a trait attached to a person and becomes his identity. Noble character is the main foundation in the formation of a perfect Muslim. In order to form a noble person, it is very important to do an early effort in building the values of noble morals, including through education. However, it is not easy to instill good morals through education. There are a number of problems encountered, namely the lack of teacher exemplary (educator); school atmosphere that is not conducive; schools are less than optimal in the actualization of morals; diverse student characters who come from diverse families; lack of communication between parents of students and schools (institutions); and the negative impact of the current modernization which is increasingly unstoppable. In this case Rasulullah SAW through some of the hadith gives a picture of morals that should be applied by educators and students in everyday life, such as; respect for educators and students, good manners in the majlis of science, being gentle and so on. The implementation of moral values can be done with the method of habituation, giving examples (daily practice), direct advice as well as criticism or satire subtly into all relevant subjects especially in religious education and citizenship, integrating moral education into activities that are programmed or planned, establishing communication or collaboration between educational institutions and parents of students, and optimizing the role models of educators.
\end{abstract}

Keywords: moral education, educators, students, prophetic traditions 
Nur Laily Fauziyah

\section{Pendahuluan}

Pada era modern ini, perkembangan ilmu pengetahuan dan teknologi semakin maju dan ketersediaan sumber daya manusia yang berkualitas menjadi tuntutan, sehingga diperlukan upaya kongkrit dalam dunia pendidikan. Upaya tersebut diantaranya dengan menyelenggarakan pendidikan akhlak, yang merupakan suatu hal yang sangat penting dalam dunia pendidikan Islam untuk melahirkan dan mencetak generasi yang islami, bermartabat dan berguna bagi masyarakat.

Pendidikan akhlak merupakan bagian dari pendidikan Islam, yang materi bimbingan dan arahannya adalah ajaran agama yang ditujukan supaya manusia percaya sepenuh hati akan adanya Tuhan, patuh dan tunduk dalam melaksanakan perintah-Nya baik ibadah maupun muamalah.

Penyelenggaraan pendidikan akhlak mengalami kesulitan sebab berhadapan dengan masalah nyata. Masalah tersebut secara langsung terkait dengan mutu pendidikan yang lebih memprioritaskan aspek keilmuan saja, tanpa memperhatikan aspek moral atau akhlak dan masa depan secara keseluruhan. Hal ini perlu dihadapi dan diatasi secara serius jika manusia ingin meningkatkan mutu kehidupan dan melihat masa depan yang tidak suram. Berbagai macam kemaksiatan yang muncul seperti perzinahan, pergaulan bebas, narkoba dan lain-lain dikarenakan kurangnya pendidikan akhlak yang dimulai dari lingkungan keluarga yang merupakan educate central yang didukung oleh lingkungan masyarakat yang islami, dan pendidikan formal maupun non formal.

Mengatasi permasalahan tersebut maka sangat perlu diupayakan para pendidik saling bekerjasama memberikan keteladanan yang baik pada peserta didik, memberikan penjelasan mana nilai-nilai akhlak yang baik dan mana nilai akhlak yang jelek atau perbuatan tercela, selanjutnya membina secara 
bertahap terus menerus agar menerapkan/mempraktikkan akhlak yang baik, membiasakannya dalam kehidupan sehari-hari serta menasehati mereka hingga menegur/mengkritiknya.

Sebagai upaya untuk menanamkan pendidikan akhlak yang baik, maka perlu mencontoh sosok seorang Nabi SAW yang diutus oleh Allah SWT untuk menyempurnakan akhlak jahiliyah menjadi akhlāq al-Karīmah. Dalam hal ini Nabi Muhammad mengajarkan dan menerapkan pendidikan akhlak kepada umatnya melalui ucapan dan perbuatannya. Di antara pendidikan akhlak Nabi Muhammad SAW adalah pendidikan akhlak peserta didik terhadap pendidiknya, yaitu tawadhu' dan sabar dalam berhijrah serta dalam menuntut ilmu. Untuk lebih detilnya akan dikaji beberapa hadis nabi berikut ini.

Permasalahan yang diangkat dalam penelitian ini yaitu; Pertama, Nilai akhlak apa saja yang terkandung dalam hadis nabi SAW.? Kedua, Bagaimana implementasi dan aktualisasi pendidikan akhlak peserta didik dan pendidik?

\section{Metode Penelitian}

Metode penelitian yang digunakan dalam penelitian ini adalah liberary research, karena sumber data yang digunakan bersumber pada jenis penelitian kepustakaan, baik sumber primer yang berfokus pada hadis-hadis dalam Kutub al-Tis'ah (Sembilan kitab hadis) yakni Sahih Bukhāri, Sahih Muslim, Sunan Abi Dāwud, Sunan al-Tirmidzi, Sunan al-Nasāeei, Sunan Ibnu Mājah, Musnad Aḥmad ibn Hanbal, Al Muwattha' Mālik dan Sunan alDārimi serta sumber-sumber sekunder yang merupakan buku-buku pendukung. Kemudian data tersebut diolah dan diterangkan dengan menggunakan penjelasan dari buku-buku hadis, ulumul hadis dan dari bukubuku tentang pendidikan akhlak. 
Nur Laily Fauziyah

Metode pengumpulan data yang digunakan adalah deskriptifinterpretasi. Metode ini adalah melukiskan dan menggambarkan objek kajian, kemudian diinterpretasikan sebagai upaya memperantai pesan yang secara eksplisit dan implisit termuat dalam realitas (hadis Nabi) sehingga pesan hadis tersebut dapat diterima dan dipahami secara jelas.

\section{Pengertian Peserta Didik dan Pendidik}

Dalam bahasa Arab, setidaknya ada tiga istilah yang menunjukkan makna peserta didik, yaitu murid, al-tilmīdz, dan al-thālib. Murid berasal dari kata 'arada, yuridu, iradatan, muridan yang berarti orang yang menginginkan (the willer). Pengertian ini menunjukkan bahwa seorang peserta didik adalah orang yang menghendaki agar mendapatkan ilmu pengetahuan, keterampilan, pengalaman, dan kepribadian yang baik untuk bekal hidupnya agar berbahagia di dunia dan akhirat dengan jalan belajar yang sungguh-sungguh. Sedangkan al-tilmīdz tidak memiliki akar kata dan berarti pelajar. Kata ini digunakan untuk menunjuk kepada peserta didik yang belajar di madrasah. Sementara al-thālib berasal dari thalaba, yathlubu, thalaban, thālibun, yang berarti orang yang mencari sesuatu. ${ }^{1}$ Hal ini menunjukkan bahwa peserta didik adalah orang yang mencari ilmu pengetahuan, pengalaman, dan keterampilan dan pembentukan kepribadiannya untuk bekal masa depannya agar bahagia dunia dan akhirat.

Kemudian, dalam penggunaan ketiga istilah tersebut biasanya dibedakan berdasarkan tingkatan peserta didik. Murid untuk sekolah dasar, al-tilmìdz untuk sekolah menengah, dan al-thālib untuk perguruan tinggi. Namun, menurut Abuddin Nata, istilah yang lebih umum untuk menyebut peserta didik adalah al-muta'allim. Istilah yang terakhir ini mencakup makna

\footnotetext{
1997), hlm.79

${ }^{1}$ Drs. Abuddin Nata, Filsafat Pendidikan Islam, (Jakarta, Logos Wacana Ilmu, - 54 -
}

Al Marhalah : Jurnal Pendidikan Islam. Volume. 2, No. 1 Mei 2018 
semua orang yang menuntut ilmu pada semua tingkatan, mulai dari tingkat dasar sampai dengan perguruan tinggi.

Peserta didik diartikan sebagai individu atau pribadi (manusia seutuhnya), peserta didik adalah anggota masyarakat yang berusaha mengembangkan potensi diri melalui proses pembelajaran yang tersedia pada jalur, jenjang dan jenis pendidikan tertentu.

Anak didik merupakan makhluk yang aktif dan kreatif juga merasa selalu membutuhkan kebebasan untuk mengembangkan daya fikirnya, oleh sebab itu pula antara pendidik dan anak didik harus mempunyai sikap yang penuh kasih sayang dan selalu berusaha untuk menciptakan suasana yang harmonis, sehingga pendidikan dapat berjalan dengan baik, bahkan justru lebih berhasil dari pada sikap kaku dan keras.

Dalam pengelolaan belajar mengajar, pendidik dan peserta didik memegang peranan penting, anak didik adalah pribadi yang "unik" yang mempunyai potensi dan mengalami proses berkembang dalam proses perkembangan itu eserta didik membuntuhkan bantuan yang sifat dan coraknya tidak ditentukan oleh pendidik tetapi oleh peserta didik itu sendiri, dalam suatu kehidupan bersama dengan individu-individu yang lain.

Fungsi peserta didik dalam interaksi belajar mengajar adalah sebagai subjek dan objek. Sebagai subjek, karena peserta didik menentukan hasil belajar. Sebagai objek, karena muridlah yang menerima pelajaran dari pendidik.

Menurut imam Al-Ghazali tugas adan kewajiban peserta didik ada 4 yaitu:

1. Mendahulukan kesucian jiwa dari kerendahan akhlak dan dari sifat-sifat yang tercela. Karena ilmu pengetahuan merupakan kabaktian hati, shalatnya jiwa dan mendekatkan batin kepada Allah Ta'ala. Jadi, belajar 
Nur Laily Fauziyah

dan mengajar adalah sama dengan ibadah shalat, sehingga shalat tidak sah kecuali dengan menghilangkan hadas dan najis, maka demikian pula dalam hal mencari ilmu, mula-mula harus menghilangkan sifat-sifat yang tercela seperti: dengki, takabbur, dan lain-lain. Namun apabila ada pelajar yang budi pekertinya buruk dan hina tapi memperoleh ilmu pengetahuan, maka ia hanya memperolehnya pada kulit dan lahirnya saja, bukan isi dan hakikatnya sehingga tidak bermanfaat bagi dirinya dan lainnya. Jadi tidak membawa kebahagiaan di dunia dan di akhirat.

2. Bersedia merantau untuk mencari ilmu pengetahuan. Apabila pengembaraan ini dilaksanakan dengan sebaik-baiknya, akan menambah pengalaman dan pengetahuan, dan menambah persahabatan juga meningkatkan persaudaraan, mendewasakan diri dan memperluas wawasan berpikir, serta mengembangkan fungsi hidup manusia.

3. Jangan menyombongkan ilmunya dan menentang gurunya

4. Mengetahui kedudukan ilmu pengetahuan.

Menurut konsep pendidikan di dalam hadits Nabi ditegaskan bahwa “Tuntutlah ilmu sejak dari ayunan sampai ke liang lahat" (H.R Abdil Bar). Telah menggambarkan bahwa pendidikan dan pengajaran itu harus dimulai sejak lahir sampai mati. Hal ini juga sesuai dengan apa yang diungkapakan oleh Anwar Jundi dalam kitabnya "at-Tarbiyah wa Bina' al-ajyal fi Dhoi Al-Islam" bahwa sesungguhnya pendidikan menurut paham islam adalah menumbuhkan manusia dengan pertumbuhan yang terus menerus sejak lahir sampai mati. Dan di Barat juga ada istilah "life long education" (pendidikan seumur hidup).

Sedangkan pengertian pendidik secara etimologi, dalam konteks pendidikan Islam pendidik disebut dengan ustadz, mu'allim, murabbi, mursyid dan mudarris. Kelima term itu, ustadz, mu'allim, murabbi, mursyid 
dan mudarris, mempunyai makna yang berbeda sesuai dengan konteks kalimat, walaupun dalam situasi tertentu mempunyai kesamaan makna.

1. Ustadz adalah orang yang berkomitmen dengan profesionalitas, yang melekat pada dirinya sikap dedikatif, komitmen terhadap mutu proses dan hasi kerja, serta sikap continuous improvement.

2. Mu'allim adalah orang yang menguasai ilmu dan mampu mengembangkannya serta menjelaskan fungsinya dalam kehidupan, menjelaskan dimensi teoretis praktisnya, sekaligus melakukan transfer ilmu pengetahuan, internalisasi, serta implementasi (amaliah).

3. Murabbi adalah orang yang mendidik dan menyiapkan peserta didik agar mampu berkreasi serta mampu mengatur dan memelihara hasil kreasinya untuk tidak menimbulkan malapetaka bagi dirinya, masyarakat, dan alam sekitarnya.

4. Mursyid adalah orang yang mampu menjadi model atau sentral identifikasi diri atau menjadi pusat anautan, teladan, dan konsultan bagi peserta didik.

5. Mudarris adalah orang yang mampu menyiapkan peserta didik untuk bertanggung jawab dalam membangun peradapan yang berkualitas di masa depan. ${ }^{2}$

Secara terminologi para pakar menggunakan rumusan yang berbeda tentang pendidik.

1. Zakiah Daradjat, berpendapat bahwa pendidik adalah individu yang akan memenuhi kebutuhan pengetahuan, sikap dan tingkah laku peserta didik.

2. Marimba, beliau mengartikan sebagai orang yang memikul pertanggungjawaban sebagai pendidik, yaitu manusia dewasa yang karena

\footnotetext{
${ }^{2}$ Drs. H. Abudin Nata, Filsafat Pendidikan Islam, hlm.100
} 
Nur Laily Fauziyah

hak dan kewajibannya bertanggung jawab tentang pendidikan peserta didik.

3. Ahmad Tafsir, mengatakan bahwa pendidik dalam Islam sama dengan teori di Barat, yaitu siapa saja yang bertanggung jawab terhadap perkembangan peserta didik.

Pendidik adalah salah satu faktor dalam proses pendidikan yang memegang peranan penting. Ia bertanggung jawab dalam emntransfer nilainilai yang telah ditetapkan oleh lembaga pendidikan untuk dimiliki oleh peserta didik. Keberhasilan aktifitas pendidikan bergantung pada keberhasilan para pendidiknya. Itulah sebabnya, Islam sangat menghormati dan menghargai orang-orang yang mau bertugas sebagai pendidik atau sebagai guru.

\section{Pendidikan Akhlak Peserta Didik dan Pendidik dalam Perspektif Hadis Nabi}

Pendidikan akhlak merupakan penanaman nilai-nilai akhlak yang telah dicontokan rasulullah SAW. melalui hadisnya. Termasuk akhlak sosial atau etika dalam kehidupan sehari-hari.

Di antara hak-hak sosial terpenting yang harus diperhatikan dan diingat oleh para pendidik yaitu mendidik diri sendiri, membina akhlak anak atau peserta didik supaya berperilaku sopan dan menghormati orangtua, guru/para pendidik dan masyarakat pada umumnya. Sebagaimana yang disampaikan dan diajarkan rasulullah SAW.

Di antara hadis nabi ${ }^{3}$ mengenai akhlak yang sebaiknya diterapkan oleh peserta didik dan pendidik adalah ;

${ }^{3}$ www.islamweb.mausu'atu al-hadis $-58-$

Al Marhalah : Jurnal Pendidikan Islam. Volume. 2, No. 1 Mei 2018 
1. Hadis tentang anjuran menghormati 'alim/pendidik

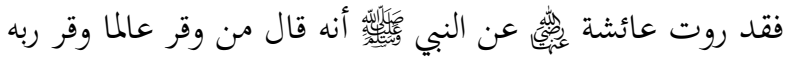

$$
\begin{aligned}
& \text { (رواه البخاري) }
\end{aligned}
$$

"Sesungguhnya 'Aisyah r.a. telah meriwayatkan dari Nabi SAW. bersabda: Barangsiapa yang menghormati orang 'alim maka sungguh ia telah menghormati Tuhannya."4

Nabi Muhammad SAW. melalui hadis tersebut mengajarkan umatnya agar selalu menghormati orang 'alim (ahli ilmu), karena hal demikian menunjukkan ketaatan dan penghormatan kepada Tuhan (Allah SWT.)

2. Hadis tentang anjuran mempermudah segala hal

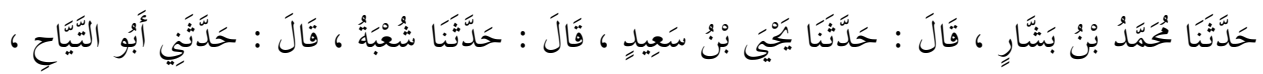

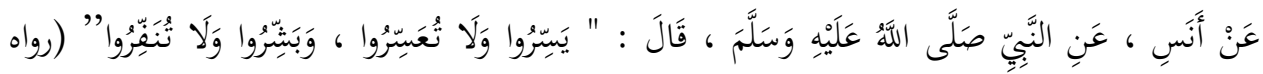

$$
\text { البخاري }
$$

"Telah menceritakan kami Muhammad bin Basyar, telah menceritakan kami Yahya bin Sa'id, ia berkata telah menceritakan kami Syu'bah, ia berkata telah menceritakan padaku Abu Tayyah, dari Anas bin Malik, dari Nabi SAW. bersabda: Permudahkanlah dan jangan persulit, dan gembirakanlah serta jangan bercerai berai”. (HR. Bukhari)

Hadis tersebut memberikan penjelasan bahwasanya jika seseorang bermuamalah atau berhubungan serta bekerjasama dengan oang lain

${ }^{4}$ Abu Al Hasan Ali bin Muhammad Al Mawardi, Adabud Dunya waddiin, (Bairut: Dar Iqra', 1985), hlm.77

Al Marhalah : Jurnal Pendidikan Islam. Volume. 2, No. 1 Mei 2018 
Nur Laily Fauziyah

sebaiknya tidak mempersulit, seperti pendidik ketika mengajarkan materi pelajaran pada peserta didiknya diharapkan menyampaikannya dengan metode yang mudah dan bisa mudah difahami peserta didiknya, bersikap ramah dan mencurahkan kasih sayangnya pada mereka sehingga para peserta didik merasakan kegembiraan, kenyamanan dan mudah menyerap pelajaran serta mudah akrab bersama guru / pendidik.

3. Hadis tentang anjuran bersikap lemah lembut

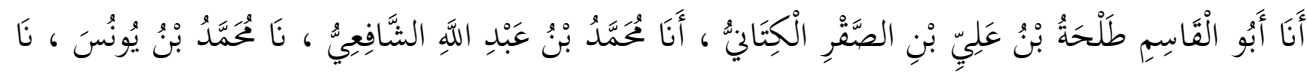

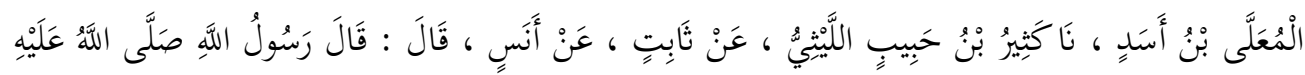

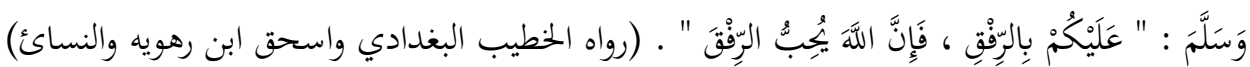

"Telah memberitakan pada kami Abu Qasim Tolhah bin Ali bin Shoqr Al-Kitaniy, telah memberitakan kami Muhammad bin Abdullah Asysyafi'I, telah memberitakan kami Muhammad bin Yunus, telah memberitakan kami Mu'alla bin Asad, telah memberitakan kami Katsir bin Hasib Allaitsi, dari Tsabit dari Anas bin Malik berkata, rasulullah SAW.bersabda: "Wajib bagimu bersikap lemah lembut, karena sesungguhnya Allah menyukai sikap lemah lembut" (HR. Al Khatib Al Baghdadi, Ishaq Ibn Rohawaih dan Annasa'i) ${ }^{5}$

Hadis di atas menginformasikan bahwa Allah SWT. senang terhadap orang yang bersikap lemah lembut, oleh karena itu seorang pendidik baik no.hadis 979

${ }^{5}$ Al Khatib Al Baghdadi, Al Jami' Li Akhlaqi Arrawi wa Adabi Assami' Al Khatib, -60 -

Al Marhalah : Jurnal Pendidikan Islam. Volume. 2, No. 1 Mei 2018 
itu guru di lembaga pendidikan maupun orangtua sebagai pendidik di lingkungan keluarga dalam mendidik anak-anaknya sebaiknya selalu menunjukkan wajah yang ramah penuh kasih sayang dan bersikap lemah lembut terhadap mereka, dengan begitu anak akan meniru sikap orangtua ataupun gurunya yang baik, anak akan selalu taat dan sopan pada orangtua juga gurunya.

4. Hadis tentang ancaman bagi orang yang menyembunyikan ilmu

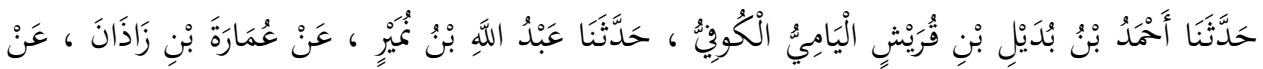

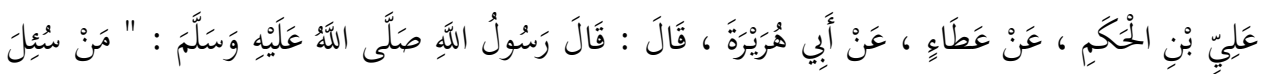

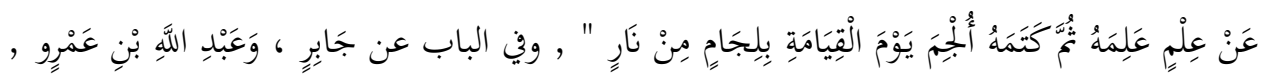

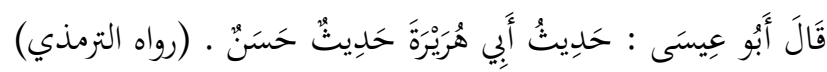

"Telah menceritakan kami Ahmad bin Budail bin Quraisy Al Yamiy Al Kufiy, telah menceritakan kami Abdullah bin Numair, dari Umaroh bin Zadzan, dari Ali bin Hakam, dari 'Atho' dari Abu Huroiroh berkata, Rasulullah SAW. bersabda: Barang siapa ditanya tentang suatu ilmu yang ia ketahui kemudian ia menyembunyikannya (tanpa menjawabnya), maka kelak ia dikendalikan di hari kiamat dengan kendali yang terbuat dari api neraka."(HR. Attirmidzi) ${ }^{6}$

Menurut keterangan para ahli hadis salah satunya yaitu 'Isa, hadis yang diriwayatkan oleh sahabat Abu Huroiroh tersebut dinilai sebagai hadis yang berderajat hasan atau di bawah tingkatan hadis sahih.

\footnotetext{
${ }^{6}$ Sunan Tirmidzi, nomor hadis 2592
} 
Nur Laily Fauziyah

Hadis tersebut menginformasikan bahwa sangat pentingnya suatu ilmu pengetahuan, maka seseorang yang sudah mendapatkan ilmu walaupun sedikit diharuskan mengamalkan atau mengajarkan serta menyampaikannya pada orang lain, jika ilmu tidak diajarkan oleh pendidik pada peserta didik maka pendidik tersebut akan dikendalikan (disiksa) pada hari kiamat nanti dengan kendali dari api neraka.

5. Hadis tentang pendidikan akhlak kesopanan.

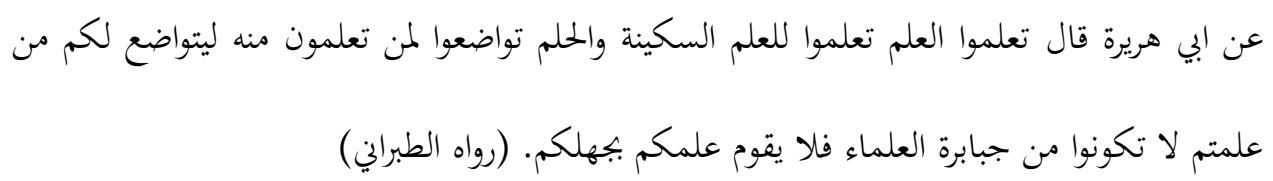

"Dari Abu Huroiroh berkata: Pelajarilah olehmu ilmu pengetahuan dan pelajarilah pengetahuan itu dengan tenang dan sopan, rendah hatilah kamu kepada orang yang mengajarkan ilmu, agar ia bersikap rendah hati kepadamu, (H.R.Thobroni)

Hadis di atas memberikan pengarahan pada seorang tholibul ilmi (pelajar dan pendidik) ketika dalam proses belajar dianjurkan agar bersikap tenang dan sopan, begitu pula seorang pendidik walaupun sudah mendapatkan ilmu tetap harus belajar (mengulang-ulang materi pelajaran) serta berperilaku sopan dan tidak menunjukkan kesombongan di hadapan peserta didik dan wali peserta didik.

Nabi Muhammad SAW merupakan sosok manusia terbaik yang menjadi panutan bagi umat sejak ia diangkat menjadi Nabi sampai menjadi Rasul sebagai utusan yang memberi kabar gembira dengan surga dan memberi peringatan atau ancaman dengan neraka. Kabar gembira maupun peringatan tersebut disampaikan Nabi kepada umatnya berupa aqidah, 
ibadah, akhlak, dan muamalah. Pendidikan akhlak yang disampaikan Nabi kepada umatnya ini melalui sabdanya, agar umatnya meniru dan melaksanakan sesuatu yang dicontohkan Nabi dalam segala aktivitas kehidupan masyarakat.

\section{Implementasi Pendidikan Akhlak Pada Peserta Didik dan Pendidik}

Melalui kajian beberapa hadis di atas, diharapkan para pendidik dan peserta didik juga umat islam pada umumnya agar mengamalkan atau mengimplementasikan nilai-nilai akhlak yang sudah dicontohkan nabi SAW.

Di antara akhlak baik peserta didik terhadap pendidik yaitu:

1. Melihat guru dengan pandangan penuh penghormatan. Termasuk salah satu cara menghormati pendidiknya yaitu tidak berjalan di depannya, tidak menduduki tempat duduknya, tidak mendahului pembicaraann/bicara di hadapan pendidiknya kecuali dengan izinnya dan sebagainya.

2. Memperhatikan hak-hak dan kewajiban pendidiknya

3. Peserta didik hendaknya tetap tabah dan sabar dalam menuntut ilmu dan dalam mendapati sikap pendidik yang kurang menyenangkan, seperti teguran keras, hukuman dan lain-lain yang semuanya itu dilakukan untuk kebaikan peserta didik

4. Memperhatikan ucapan dan perkataannya saat berada di hadapan pendidik. Begitu juga sikap duduknya tidak menunjukkan bermalasmalasan, kedua tangannya tidak bertumpu ke belakang dan sebagainya. 
Nur Laily Fauziyah

5. Meminta izin sebelum berbicara dan tidak mengeraskan suaranya di hadapan guru/pendidiknya

Adapun seorang pendidik juga harus menunjukkan akhlak baiknya (memberi contoh yang baik terhadap peserta didiknya serta wali muridnya), di antaranya:

1. Ikhlas dalam mengamalkan ilmunya atau megajarkan ilmunya pada peserta didik. Hendaknya membimbing peserta didik agar belajar bukan karena ijazah semata, atau mengejar jabatan, popularitas, dan kemewahan dunia, sebab semua itu bisa mengarah pada sifat materialistic.

2. Seorang pendidik harus membimbing/mendidik peserta didiknya dengan tekun dan penuh kesabaran. Mengajarkan muridnya agar mempelajari ilmu secara sistematis, setahap demi setahap melalui proses yang panjang dan banyak ujian.

3. Seorang pendidik harus mencintai dan menyayangi peserta didiknya seperti mencintai diri sendiri dan anak-anaknya (keluarganya). Sifat kasih sayang inilah yang pada akhirnya akan melahirkan keakraban, menjadikan peserta didik lebih percaya diri, serta mendapatkan ketentraman dalam belajar, sehingga mudah menyerap atau memahami ilmu yang didengar dari pendidiknya.

4. Seorang pendidik menyampaikan ilmu sesuai dengan kadar kemampuan peserta didik. Sebagaimana yang dicontohkan rasulullah saw. dan para sahabat seperti sayyidina Ali karramallahu wajhah berkata: "Ajaklah bicara seseorang itu sesuai dengan kemampuan akal mereka”. 
5. Hilangkan kebiasaan yang dapat mendidik mereka (peserta didik) untuk bertingkah laku atau bertutur kata yang tidak baik. Pendidik sebagai teladan bagi para peserta didiknya hendaknya mencontoh sikap rasulullah saw., apa yang keluar dari lisannya sama dengan apa yang ada di dada/hatinya, sehingga perbuatannya pun sama dengan perkataannnya.

6. Tidak menjelekkan ilmu agama tertentu. Ketika seorang pendidik 'alim atau ahli dalam bidang ilmu fiqh maka dia tidak mengecilkan atau meremehkan para ahli di bidang ilmu hadis, tafsir dan lain sebagainya, sebaliknya ia harus memberikan nasehat dan peluang pada peserta didiknya untuk mengkaji berbagai bidang ilmu pengetahuan.

7. Hendaknya seorang pendidik menghindari perhatian yang tidak seimbang di antara peserta didiknya, tidak pilih kasih. Tidak boleh seorang pendidik memberi perhatian istimewa pada salah seorang peserta didiknya yang memiliki kecantikan lebih, ketampanan, kecerdasan lebih serta kedudukan yang mulia dari orangtuanya.

8. Hendaknya seorang pendidik berwajah ceria, ramah dan selalu senyum di hadapan peserta didik serta wali muridnya, menunjukkan seorang 'alim yang berwibawa, menjaga dan mempertahankan kemuliaannya. $^{7}$

Menurut Prof. Dr. Athiyah Al-Abrasyi, seorang pendidik harus memiliki sifat-sifat tertentu agar ia dapat melaksanakan tugasnya dengan baik. Sifat-sifat tersebut ialah :

${ }^{7}$ Adib Dailami dkk., Hadits Akhlak, (MUI DKI Jakarta, 2014), hlm. 56

Al Marhalah : Jurnal Pendidikan Islam. Volume. 2, No. 1 Mei 2018 
Nur Laily Fauziyah

a. Zuhud, tidak mengutamakan materi dan mengajar karena mencari keridhaan Allah semata.

b. Seorang pendidik harus jauh dari dosa besar, sifat riya (mencari nama), dengki, permusuhan perselisihan dan lain-lain sifat yang tercela.

c. Seorang pendidik harus bersifat pemaaf terhadap murid/peserta didiknya, ia sanggup menahan diri, menahan kemarahan, lapang hati, berkepribadian dan mempunyai harga diri.

d. Seorang pendidik harus menguasai ilmu yang akan diberikan pada peserta didiknya, dan benar-benar mampu mengamalkan dalam kehidupan sehari-hari, sehingga bisa ditiru dan diamalkan oleh peserta didiknya. ${ }^{8}$

Aktualisasi pendidikan akhlak dapat ditempuh melalui beberapa strategi, yaitu; Pertama, dengan mengintegrasikan konten kurikulum pendidikan akhlak yang telah dirumuskan ke dalam semua mata pelajaran yang relevan terutama dalam pendidikan agama serta kwarganegaraan. Kedua, mengintegrasikan pendidikan akhlak dalam kegiatan yang diprogramkan atau direncanakan. Ketiga, membangun komunikasi atau kerjasama antara lembaga pendidikan dengan orang tua peserta didik. Keempat, mengoptimalkan keteladanan para pendidik.

Di samping itu untuk menyelaraskan pembentukan akhlak perlu adanya pendekatan profetik (pendekatan kenabian), yaitu; Pertama, mendekatkan peserta didik pada kitab suci. Kedua, mendekatkan peserta didik pada tempat ibadah. Ketiga, mendekatkan peserta didik dengan para pendidik.

${ }^{8}$ Drs.H.Hamdani Ihsan dan Drs.H. A.Fuad Ihsan, Filsafat Pendidikan Islam, (Bandung, Pustaka Setia, 2007), hlm. 105

- 66 -

Al Marhalah : Jurnal Pendidikan Islam. Volume. 2, No. 1 Mei 2018 
Adapun implementasi pendidikan akhlak bagi peserta didik tingkat sekolah dasar dapat dilakukan melalui petunjuk dan nasehat secara langsung dengan bahasa sederhana yang sesuai dengan perkembangan kecerdasan dan daya pikirnya. Dalam hal ini dapat digunakan syair dengan lagu yang menarik bagi anak-anak, kata-kata indah yang diucapkan dengan irama lagu yang menarik akan ditiru dan diulang-ulang serta dipraktekkan oleh anak, lambat laun akan diserap ke dalam hatinya, selanjutnya ia akan terdorong untuk melakukannya.

Pendidikan akhlak dapat pula memanfaatkan bakat, naluri dan kecenderungan anak, misalnya suka meniru, melakukan identifikasi terhadap kata-kata, perbuatan, gerakan dan sikap diam pada orang-orang yang sering berhubungan dengan mereka, salah satunya guru/pendidiknya. Oleh karena itu keimanan, akhlak serta kepribadian guru/pendidik amat penting dalam pembinaan akhlak peserta didik.

Sedangkan pembinaan akhlak anak remaja atau peserta didik pada tingkatan sekolah menengah pertama sudah dapat dilakukan secara langsung dengan nasehat, petunjuk dan penjelasan langsung tentang berbagai hal yang baik dan bermanfaat serta hal-hal yang buruk dan membahayakan. Hal ini bisa dengan menegur, mengkritik hal-hal yang tercela serta menghukumnya.

Tidak kalah pentingnya, bagi para pendidik dalam mengimplementasikan nilai-nilai akhlak bisa dimulai dari diri sendiri dan mengajak pendidik yang lain di lingkungan lembaga pendidikan, yakni setiap hari dalam menyambut para peserta didik dan wali mereka agar menunjukkan wajah/muka yang ceria, ramah, terbiasa senyum, sapa, salam, salim, selain itu membiasakan disiplin datang lebih awal dari yang lainnya, menunjukkan sikap rendah hati ketika mengajarkan ilmu di 
Nur Laily Fauziyah

kelas, tidak merasa paling pintar sehinngga sering menguasai materi pelajaran sendiri, sebaiknya memberi kesempatan pada para peserta didik agar lebih aktif bertanya atau memberikan tambahan materi dan sebagainya.

Pendidikan akhlak anak didik terhadap para pendidik dapat menghantarkan mereka kepada sa'adah (kebahagiaan) yang hakiki yakni manusia yang sempurna sebagaimana seorang filosof yang telah mencapai pencerahan tingkat tinggi. Selain itu, dapat membentuk manusia yang penuh hikmah (bijaksana) shaja ${ }^{\text {ee } a h ~(b e r a n i) ~ d a n ~ i f f a h ~}$ (mengendalikan diri) dan berlaku adil (al-,,Adalah). Hal tersebut bisa terbentuk jika pendidikan akhlak tersebut diterapkan sejak kecil melalui proses pendidikan formal maupun non formal dalam bentuk pembelajaran

\section{Penutup}

Nilai-nilai akhlak yang terkandung dalam beberapa hadis di atas yaitu akhlak seorang pendidik agar mempermudah peserta didik sebaliknya tidak mempersulit, materi ilmunya diambil yang paling mudah atau disesuaikan kemampuan akal pikiran peserta didik, akhlak peserta didik terhadap pendidik agar mereka saling menghormati yang lebih tua (guru), akhlak pendidik agar tidak pelit ilmu (tidak menyembunyikan ilmu), akhlak kesopanan bagi peserta didik dan pendidik dalam majlis ilmu.

Implementasi pendidikan akhlak bagi peserta didik tingkat sekolah dasar dapat dilakukan melalui petunjuk dan nasehat secara langsung dengan bahasa yang sangat sederhana, pembinaan akhlak anak usia remaja dilakukan dengan menasehati mereka, menegur serta mengkritik/menyindir secara halus dan bila perlu menghukumnya jika $-68-$

Al Marhalah : Jurnal Pendidikan Islam. Volume. 2, No. 1 Mei 2018 
didapati mereka (peserta didik) berlebihan dalam melakukan perbuatan tercela di lingkungan lembaga pendidikan / sekolahan.

Aktualisasi pendidikan akhlak dapat ditempuh dengan cara; mengintegrasikan konten kurikulum pendidikan akhlak yang telah dirumuskan ke dalam semua mata pelajaran yang relevan terutama dalam pendidikan agama serta kwarganegaraan. Mengintegrasikan pendidikan akhlak dalam kegiatan yang diprogramkan atau direncanakan. Membangun komunikasi atau kerjasama antara lembaga pendidikan dengan orang tua peserta didik. Terakhir, mengoptimalkan keteladanan para pendidik.

\section{Daftar Pustaka}

Adib Dailami dkk., Hadits Akhlak, MUI DKI Jakarta, 2014

Al Mawardi, Abu Al Hasan Ali bin Muhammad, Adabud Dunya waddiin, Bairut: Dar Iqra', 1985

Hamdani Ihsan dan Fuad Ihsan, Filsafat Pendidikan Islam, Bandung, Pustaka Setia, 2007.

http:/subahri/ISLAMUNA/ejournal.stainpamekasan.ac.id/index.php/islamuna /article/

Mahmud, Ali Abdul Halim, Tarbiyah Khuluqiyah, terj., Solo: Media Insani, 2003

Nata, Abuddin, Filsafat Pendidikan Islam, Jakarta, Logos Wacana Ilmu, 1997

Rama Furqona (ed.), Pendidikan Agama dan Akhlak bagi Anak dan Remaja, Ciputat:, Logos Wacana Ilmu, 2002

Syafe'I, Rachmat, Al Hadis, Bandung: Pustaka Setia, 2000 
Nur Laily Fauziyah

Ulwan, Abdullah Nashih, Pendidikan Anak Dalam Islam, terj., Jakarta: Pustaka Amani, 2007

'Ulama'I, Hasan Asy'ari, Hadis-Hadis Pendidikan Mental, Semarang: Fakultas Tarbiyah IAIN Walisongo, 2008

www.islamweb.mausu'atu al-hadis 